Journal of Biomedical and Pharmaceutical Research

Available Online at www.jbpr.in

CODEN: - JBPRAU (Source: - American Chemical Society)

PubMed (National Library of Medicine): ID: (101671502)

Index Copernicus Value 2018: 88.52

Research Article
ISSN (Online): 2279-0594

ISSN (Print): 2589-8752

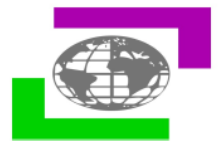

\title{
FORMULATION AND EVALUATION OF NIFEDIPINE SUSTAINED RELEASE TABLETS BY USING DIFFERENT POLYMERS
}

\author{
Shraddha Pawan Pareek ${ }^{1 *}$, Sunil Kumawat ${ }^{2}$, Vijay Sharma ${ }^{2}$, Devender Sharma ${ }^{2}$, Devendra Singh Rathore ${ }^{2}$ \\ ${ }^{1 *}$ Research Scholar, Goenka College of Pharmacy, Lachhmangarh, Sikar, Rajasthan (India) \\ ${ }^{2}$ Department of Pharmaceutics, Goenka College of Pharmacy, Lachhmangarh, Sikar, Rajasthan (India)
}

Article Info: Received 02 September 2019; Accepted 18 November. 2019

DOI: https://doi.org/10.32553/jbpr.v8i6.684

Address for Correspondence: Shraddha Pawan Pareek

Conflict of interest statement: No conflict of interest

\section{ABSTRACT:}

Oral drug delivery has been known for many years because the most generally utilized route of administration among all the routes that are explored for the general delivery of medication via various pharmaceutical products of different dosage forms. The reason that the oral route achieved such quality could also be partly attributed to its simple administration moreover because the ancient belief that by oral administration the drug is well absorbed because the food stuffs that area unit eaten daily. In fact the event of a pharmaceutical product for oral delivery, no matter its physical kind involves variable extents of optimization of dose kind characteristics at intervals the inherent constraints of GI physiology. The rationale for development of a extended release formulation of a drug is to enhance its therapeutic benefits, minimizing its side effects while improving the management of the diseased condition. The aim of the present investigation is to formulate and evaluate matrix tablets of Nifedipine using a mixture of polymers in view to sustain the drug release, reduce frequency of administration and improved patient compliance. In this research paper all evaluation parameter and stability studies also well discussed in well manner.

Keyword Matrix Tablets, Coating, Novel Drug Delivery System, Sustained Release Tablets

\section{INTRODUCTION:}

Sustained- release dosage forms it is defined as "any drug or dosage form modification that prolongs the therapeutic activity of the drug". Sustained release formulations can offer many pharmacokinetic and Pharmacodynamic advantages over conventional dosage forms, including maintenance of constant therapeutic levels for a longer period of time and reduction of fluctuations in plasma drug concentrations. Sustained release formulations can reduce the risk of treatment failure due to inadequate dosing of antibiotics. Nifedipine has bioavailability of $45-56 \%$, protein binding of $92-98 \%$ and its half-life is about 2 hours and it undergoes gastrointestinal and hepatic metabolism So, In the present study, aim is for preparation and evaluation of sustained release matrix tablets of Nifedipine, in order to overcome first-pass effect, dose related side effects, dosing frequency, problems in disease control and many other difficulties.

\section{MATERIALS AND METHOD}

\section{Chemicals and Reagents}

Nifedipine Hydrochloride was supplied by Glow Pharma Ltd, Vasai, Maharashtra and Hydroxypropylmethylcellulose K100M, Ethylcellulose, Polyvinyl pyrollidone K-30, Magnesium Stearate, Aerosil, Lactose, Talc was also supplied by Glow Pharma Ltd, Vasai, Maharashtra

\section{Preformulation Studies}

Preformulation testing is the first step in rational development of dosage forms of a drug Substance. Preformulation study is the process of optimizing the delivery of drug through Determination of physicochemical properties of the excipients that could affect drug performance and development of as efficacious, stable and safe dosage form. ${ }^{1}$ It provides a framework for the drug combination with pharmaceutical excipients in the dosage form. Determination of $\lambda$ max of Nifedipine was dissolved 
in methanol further diluted with the same and scanned for Maximum absorbance in UV double beam spectrophotometer (Shimadzu 1800) in the range from 190 to $380 \mathrm{~nm}$.

Appearance:

Visual Examination- A small quantity of Nifedipine was taken in a butter paper and viewed in well illuminated Room.

\section{Solubility}

The solubility of Nifedipine is determined by acetone in chloroform, ethanol and water.

Table 1: Solubility Parameter ${ }^{2}$

\begin{tabular}{ll}
\hline Descriptive team & $\begin{array}{l}\text { Parts of solvent required } \\
\text { for } 1 \text { part of solute }\end{array}$ \\
\hline Very soluble & Less than 1 \\
\hline Freely soluble & From 1 to 10 \\
\hline Soluble & From 10 to 30 \\
\hline Sparingly soluble & From 30 o 100 \\
\hline Slightly soluble & From 100 to 1000 \\
\hline Very slightly soluble & From 1000 to 10000 \\
\hline Practically insoluble or & Greater than or equal to \\
insoluble & $10,000$. \\
\hline
\end{tabular}

Melting point

Melting point of the Nifedipine was determined by capillary method in triplicate.

\section{Assay}

Weigh $25 \mathrm{mg}$ Nifedipine, dissolve a mixture of $100 \mathrm{ml}$ of methanol and take blank $2 \mathrm{ml}$ of $0.1 \mathrm{M}$ hydrochloric acid and sample equivalent to $25 \mathrm{mg}$ Nifedipine ,dissolve a mixture of $100 \mathrm{ml}$ of methanol and take blank $2 \mathrm{ml}$ of $0.1 \mathrm{M}$ hydrochloric acid and take U.V. spectroscopy $\lambda$ max of Nifedipine observe at $340 \mathrm{~nm}$.

\section{Compatibility studies}

The proper design and formulation of a dosage from require consideration of the physical, chemical and biological characteristics of the ingredients used in fabricating the formulation i.e. drug and excipients in the formulations. The drug an excipients should be compatible with one another to produce stable efficacious, attractive an easy to administer and safe dosage form. If the excipients are new and not been used in the formulation containing the active substance, the compatibility are of paramount importance .hence FTIR spectra Active with Nifedipine is compared with different excipients. ${ }^{3}$

\section{Spectroscopy}

FT-IR spectroscopy was carried out to check the compatibility between drug and excipients.

Infrared spectroscopy was conducted using burker and the spectrum was Recorded in the region of 4000 to $400 \mathrm{~cm}-1$. The samples (drug and drugexcipient mixture in 1:1 ratio. The interaction between drug-excipients was observed from IRspectral studies by observing any shift in peaks of drug in the spectrum of physical mixture of drug excipients. ${ }^{4,23, \text { and } 24,25,26,27}$

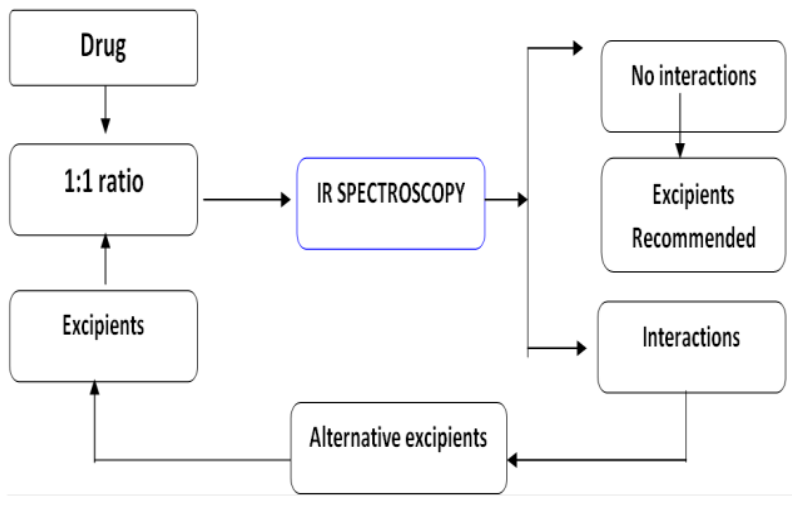

Fig 1 FT-IR spectroscopy ${ }^{5}$

\section{Manufacturing Process of the Sustained Release Tablets of Nifedipine}

In the present investigation sustained release tablets of Nifedipine tablets were prepared by using wet granulation technique. ${ }^{6}$ Steps included in the manufacturing process are by sifting $\&$ dry mixing:

- The active material and excipeints were passed through 60\# and 100 \# sieve respectively

- And then mix the material in granulator close the lid and allow it to rotate for 5 mins.

- Total time required was 15 mins

\section{Binder Preparation}

- Mix the material in the vessel and pour the solvent continuously stir it using the ladle.

- Stir it constantly until the desired consistency is observed.

- Allow the paste to cool at room temperature. 
- Total time required for preparation of binder was 30 mins using isopropyl alcohol lactose ad ethyl cellulose

\section{Wet granulation}

- Mix the binder solution with the powder mixture to form wet mass

- Wet granulation is used using the RMG.

- All the material were mixed at slow speed and fast speed.

- An stopped when the ampere reading reached at 25 am

Drying

- Drying is done using FBD.

- Load the material in the FBD and FBD bags are fitted. And the temperature is adjusted in the inlets and outlet by putting on the heater.

- Start the FBD $15 \mathrm{~min}$ and put off the heater and adjust the heater and stop after $15 \mathrm{~min}$.

- Rake the material in bowl up and down with spatula for $3 \mathrm{~min}$.

- $\quad$ Put the heater and adjust the temperature.

- Put off the heater And Stop the FBD and shake the FBD Bags.

- Total time required to complete drying is $\mathbf{4 5}$ $\min$.

\section{Sizing}

- Check and ensure that all sieves are cleaned.

- $\quad$ Sift the material through 18 \# sieve and dried material through vibratory sifter and collect.

- Mill the leftover through multimills.

- Granules should be cooled before lubrication.

- Screen size should be $1.5 \mathrm{~mm}$.

Lubrication

- Collect the sifted material through 60\#and 40 $\#$.

- And magnesium stearate was passed through $100 \#$ and it was added after sifting in a different container

- First take out the fines.

- Then mix the lubricants for Close the octagonal blender and Allow to rotate the blender.

- Stop octagonal blender.

- And collect the granules in the container.

\section{Compression}

- $\quad$ Set the rotary tablets compression machines \& set the machine as per the physical parameter mentioned.

- Add granules in the hopper of the compression machine and check the flow of granules to feed frames
- All tablets were compressed on single punch i.e. $8.6 \mathrm{~mm}$ single punch as per company requirement with circular flat look with a breakline on one side

\section{Coating}

- Transfer the tablets uncoated tablets area to coating tablets.

- $\quad$ Fit spray gun and nozzle transfer the coating solution to the coatin solution.

- Start the pan to roll and start spaying the coating solution over the tablet bed after adjusting the parameter including.

1. Air pressure

2. Temperature of hot air blower

3. Bed temperature.

4. Exhaust

\section{Coating conditions}

Table 2: Coating Conditions ${ }^{7}$

\begin{tabular}{ll}
\hline Parameters & Conditions \\
\hline Pan speed & 8 to $10 \mathrm{rpm}$ \\
\hline Inlet air temperature & 30 to $40{ }^{\circ} \mathrm{C}$ \\
\hline Exhaust air temperature & 30 to $35^{\circ} \mathrm{C}$ \\
\hline Bed temperature & 30 to $35^{\circ} \mathrm{C}$ \\
\hline Atomizing air pressure & 3 to $4 \mathrm{~kg} / \mathrm{cm}^{2}$ \\
\hline Spray gun nozzle diameter & $1.0 \mathrm{~mm}$ \\
\hline Spray rate & 6.0 to $8.0 \mathrm{ml} / \mathrm{min}$ \\
\hline
\end{tabular}

Preparation of Coating Solutions ${ }^{8}$

- All the ingredients were weighed and dispensed.

- Color sunset yellow lake and Titanium Dioxide was added in IPA.

- $\quad$ PEG-600, HPMC and purified talc were added in Methylene dichloride

- Both were mixed together and stirred together to get a homogenous mixture

- The prepared suspension is strained through 100 \#sieve.

The initial check on the tablet were carried out after film coating, appearance, average weight, Thickness of tablet ,Disintegration time and drug release were also checked.

\section{Blister Packing of Tablets ${ }^{9}$}

White colored PVC-PVDC base foil and Aluminium lidding foil are loaded in the machine .The tablets were loaded in the hopper. The base foil passes through the forming units with Teflon heads and cavities are formed. Tablets in the hopper coming down through inclined feeding channel and singling 
unit and are introduced into the cavities formed. The heat sealable Aluminium lidding foil is introduced and the sealing of the foils was done in the sealing station. The non-filled cavities are detected using non fill detecting system and are rejected. The cutting assembly and the trimming station cuts the blister into appropriate size and shape. Here the thickness of PVC/ PVDC layer is $0.850 \mathrm{~mm}$ while thickness of Aluminium foil is $0.400 \mathrm{~mm}$.

Evaluation of Preformulation Parameters:

\section{Angle of Repose ${ }^{10}$}

The angle of repose of granules was determined by the funnel method. The accurately weighed granules were taken in a funnel. The height of the funnel was adjusted in such a way that the tip of the funnel just touched the apex of the heap of the granules. The granules were allowed to flow through the funnel freely onto the surface. The diameter of the powder cone was measured and angle of repose was calculated using equation. $\theta=\tan ^{-1}(h / r)$

Where, $\theta=$ the angle of repose

$\mathrm{h}=$ height of the heap of the powder

$r=$ radius of the heap of the powder

Table 3: Angle of Repose ${ }^{11}$

\begin{tabular}{lll}
\hline Sr. No & Angle of $\operatorname{Repsoe}(\boldsymbol{\theta})$ & Type of flow \\
\hline 1 & $<25$ & Excellent \\
\hline 2 & $25-30$ & Good \\
\hline 3 & $30-40$ & Passable \\
\hline 4 & $>40$ & Very poor \\
\hline $\begin{array}{l}\text { Determination of bulk density and tapped density } \\
12,13\end{array}$
\end{tabular}

A quantity of $2 \mathrm{~g}$ of the powder (W) from each formula was introduced into a $25 \mathrm{ml}$ measuring cylinder. After the initial volume was observed, the cylinder was allowed to fall under its own weight onto a hard surface from the height of $2.5 \mathrm{~cm}$ at 2 sec intervals. The tapping was continued until no further change in volume was noted. The bulk density, and tapped density were calculated using following formulas.

$$
\begin{aligned}
\mathrm{Db}= & \text { Mass of powder } \\
& \text { Bulk volume of the powder } \\
\mathrm{Dt}= & \text { Mass of powder } \\
& \text { Tapped volume of the powder }
\end{aligned}
$$

\section{Carr's index ${ }^{14}$}

It helps in measuring the force required to break the friction between the particles and the hopper. It is expressed in \% and given by

Carr's index \% = Tapped Density - Bulk Density X100/Tapped Density

Table 4: \% Compressibility Index

\begin{tabular}{lll}
\hline $\begin{array}{l}\text { Sr. } \\
\text { No }\end{array}$ & \% Compressibility & Index Property \\
\hline 1 & $5-12$ & Free flowing \\
\hline 2 & $12-16$ & Good \\
\hline 3 & $18-21$ & Fair \\
\hline 4 & $23-35$ & Poor \\
\hline 5 & $33-38$ & Very poor \\
\hline 6 & $6>40$ & Extremely poor \\
\hline
\end{tabular}

\section{Hausner's ratio ${ }^{15}$}

Hausner's ratio is a indirect index of ease of powder flow. Hausner's ratio was measured by the ratio of tapped density to bulk density.

Hausner's ratio $=$ Tapped Density/Bulk density

Table 5: Hausner's ratio

\begin{tabular}{llll}
\hline Sr no. & $\begin{array}{l}\text { Hausner's } \\
\text { Property }\end{array}$ & ratio & Property \\
\hline 1 & $0-1.2$ & Free flowing \\
\hline 2 & $1.2-1.6$ & Cohesive flowing \\
\hline
\end{tabular}

\section{EVALUTION OF COMPRESSED TABLETS ${ }^{16}$}

\section{Evaluation of Nifedipine sustained release Tablet}

The tablets prepared were evaluated for the following parameters like weight variation, hardness, friability, drug content, in-vitro dissolution studies and, stability studies.

Weight Variation Test ${ }^{17,18}$

To study weight variation, 20 tablets of each formulation were weighted using electronic balance and the test was performed according to the official method.

Table 6: IP standards of Uniformity of weight

\begin{tabular}{lll}
\hline Sr no. & Avg. Wt of Tablet (mg) & \% Deviation \\
\hline 1 & $>80 \mathrm{mg}$ & $10 \%$ \\
\hline 2 & $80 \mathrm{mg}-250 \mathrm{mg}$ & $7.5 \%$ \\
\hline 3 & $\geq 250 \mathrm{mg}$ & $5 \%$ \\
\hline
\end{tabular}




\section{Hardness ${ }^{19}$}

Hardness of tablets was tested using the Monsanto hardness tester .the tester consist of barrel containing a compressible spring held between two plunger .the lower plunger is placed in contact with tablet with a zero reading taken. The upper plunger is than forced against a spring by turning a threaded bolt until the tablet fractures and then the force of fracture was recorded in all the average of six tablets were used for determination

\section{Friability ${ }^{19}$}

Friability generally refers to loss in weight of tablets in the containers due to removal of fines from the tablet surface. Friability generally reflects poor cohesion of tablet ingredients.10 gm were weighed and the initial weight of these tablets was recorded and placed in Roche friabilator and rotated at the speed of $25 \mathrm{rpm}$ for 100 revolutions. Then tablets were removed from the friabilator dusted off the fines and again weighed and the weight was recorded. Percentage friability was calculated by using the formula.

$\%$ Friability $=$ Weight of initial tablets- Weight of final tablets X 100/ Weight of initial tablets

\section{Tablet Thickness}

Thickness of the tablet is important for uniformity of tablet size. Thickness was measured using Vernier Calipers. It was determined by checking the thickness of ten tablets of each formulation. Vernier caliper consists of metric and imperial scales. The main matric scale is read first then read

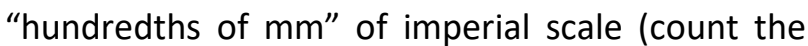
number of division until the lines concedes with the main metric scale. The imperial scale number is multiply with 0.02 . Then that number obtained from imperial scale added with main metric scale to get final measurement.

Disintegration time ${ }^{5,19}$

The disintergration time was determined using disintegration test apparatus at $37^{\circ} \mathrm{C} \pm 2^{\circ} \mathrm{C}$. A tablet was placed in each of the six tubes of the apparatus a one disc is added to each tube then time taken for the complete disintegration of the tablets with no palpable mass in the apparatus was noted.

In vitro dissolution studies of sustained release layer ${ }^{20,21}$

The in vitro release of sustained release layer was carried out for hours using USP type-II apparatus
(DT-1200) at $150 \mathrm{rpm}$ for the first $120 \mathrm{mins}$ in 900 $\mathrm{ml} 0.1 \mathrm{~N} \mathrm{HCL}$ at $340 \mathrm{~nm}$ maintaining at $37 \pm 0.50 \mathrm{C}$ and then at phosphate buffer $\mathrm{pH} 6.8$ in $900 \mathrm{ml}$ for another 6 hour. A $5 \mathrm{ml}$ was withdrawn at different time intervals and replaced with an equal volume of fresh medium. The samples were suitably diluted with blank dissolution medium, filtered and analyzed on UV spectrophotometer at $340 \mathrm{~nm}$.

\section{Drug Content for Sustained Release layer}

Ten tablets were weight and average weight is calculated. All tablets were crushed and powder equivalent to $100 \mathrm{mg}$ drug was dissolved in $\mathrm{pH} 6.8$ phosphate buffer and the volume was made up to $100 \mathrm{ml}$ with $\mathrm{pH} 6.8$ phosphate buffer. The solution was kept in solicitor for $1 \mathrm{hr}$. From the stock solution, $1 \mathrm{ml}$ solution was taken in $10 \mathrm{ml}$ volumetric flask and the volume was made with pH6.8 phosphate buffer. Solution was filtered and absorbance was measured spectrophotometrically at $350 \mathrm{~nm}$ against pH6.8 phosphate buffer as a blank. Amount of drug present in one tablet was calculated.

Mathematical Modeling of drug Release Profile ${ }^{23,}$ $24,25,26,27$

The cumulative amount of release from the formulated tablets at Different time intervals were fitted to Zero order kinetics, first order kinetics, Higuchi model and korsmeyer-peppas model to characterize mechanism of drug release.

1. Zero-order Kinetic model - Cumulative \%drug release versus Time.

2. first-order Kinetic model - Log cumulative \% drug remaining versus Time.

3. Higuchi's model - cumulative percent drug released versus square root of time.

4. Korsmeyer equation / peppa's model- Log cumulative percent drug released versus log time.

\section{Zero order kinetic}

It describes the system in which the release rate is independent of its concentration.

$\mathrm{Qt}=\mathrm{Q}_{0}+\mathrm{K}_{0} \mathrm{t}$

Where, $\mathrm{Qt}=$ amount of drug dissolved in time $\mathrm{t}$

$\mathrm{Q}_{0}=$ initial amount of drug in the solution

$\mathrm{K}_{0}=$ zero order release constant

If the zero order drug release kinetic is obeyed, a plot of $Q t$ versus $t$ will give straight line with a slope of $\mathrm{K}_{0}$ and an intercept at $\mathrm{Q}_{0}$.

First order kinetics

The application of this model to drug dissolution studies was first proposed byGibaldi and Feldman 
(1967) and later by Wagner. The dissolution phenomena impliesa surface action, as can be seen by Noyes-Whitney equation,

$\frac{d c}{d t}=K(C s-C)$

Where, $\mathrm{C}=$ Concentration of solute in time $\mathrm{t}, \mathrm{CS}=$ solubility in equilibrium at experience temperature, $\mathrm{k}=$ First order proportionality constant

Hixson and Crowell adapted the above equation as $\frac{d w}{d t}=K(C s-C)$

Where, $w=$ amount of solute in solution at time $t$, $S=$ Solid area accessible to dissolution.

$\log Q_{t}=\log Q_{0}+K 1 . t / 2.303$

Where, $\mathrm{Q}_{\mathrm{t}}=$ amount of drug release in time $\mathrm{t}, \mathrm{Q}_{0}=$ initial amount of drug in solution,

$\mathrm{K}_{1}=$ First order release constant.

Above equation also represents this model.

The pharmaceutical dosage form following this dissolution profile, such asthose containing water soluble drugs in porous matrices release drug in a way that is proportional to amount of drug remaining in its interior in such a way that amount of drug released by unit of time diminish.

\section{Higuchi Model}

Higuchi developed mathematical expressions for drugs particles dispersed in a uniform matrix behaving as diffusion media. To study the dissolution form a planar system having a homogeneous matrix, the relation obtained was

$\mathrm{Ft}=\mathrm{Q}=\sqrt{(2 C-C s) C s t}$

Where, $Q=$ Amount of drug released in time t per unit area, $C=$ Drug initial concentration

$\mathrm{CS}=$ drug solubility in matrix media, $\mathrm{D}=$ Diffusivity of drug molecules in matrix substance.

The solid line represents the variation of drug concentration in the pharmaceutical system after time t. To distance $h$, the concentration gradient will be constant, provided $C>>C_{s}$. The linearity order follows the Fick's law.

$\mathrm{Q}=\sqrt{t D C s(2 C-C s}$

Relation is valid during all time except when the total depletion of drug in therapeutic system is achieved .Higuchi developed other models for release from heterogeneous matrix, when the drug concentration in matrix is lower than its solubility and the release occurs through pores in matrix, the obtained relation is:

$\mathrm{Ft}=\mathrm{Q}=\sqrt{D E / T(2 C-\varepsilon C s}) C s t$

\section{Korsmeyer and Peppas model}

This equation is useful to study the diffusion / relaxation release of dosage form as well zero order release kinetics. The equation can be described as

$\frac{M t}{M \infty}=K t^{n}$

$\frac{M t}{M \infty}=$ fraction of drug release in time $\mathrm{t}$,

$\mathrm{K}=$ constant incorporating structural and geometric characteristics of controlled release device.

$\mathrm{n}=$ diffusion release exponent indicative of release Mechanism. For release from swellable cylinders Ritger and Peppas have indicated,

$\mathrm{n}=0.45$ for Fickian diffusion,

$\mathrm{n}>0.45$ and $<0.89$ for anomalous diffusion or non

Fickian diffusion $(0.5<\mathrm{n}<1)$

$\mathrm{n}=0.89$ for zero order release

$\mathrm{n}=1$ or $>1$ for super case

STABILITY STUDIES ${ }^{23,24,25,26,27}$

\section{Stability Testing of the Optimized Formulation}

Stability studies of the drug has been defined as the ability of a particular formulation in la specific container to remain within its physical ,chemical, therapeutic and toxicological specifications. The purpose of stability study is to provide evidence on the quality of a drug substance or drug product which Varies with time under the influence of variety of environmental factors such as temperature ,humidity and light .recommended storage conditions, re-test period and shelf lies are to be established. The international conference of harmonization (ICH) Guidelines titled, "stability testing of a new drug Substances and products" describes the stability test requirement for drug registration application of European Union, Japan and USA.

Long term stability

(I) $30+2{ }^{\circ} \mathrm{C}$ and $\mathrm{RH} 65 \%+5 \%$

Accelerated studies

(II) $40+2{ }^{\circ} \mathrm{C}$ and $\mathrm{RH} 75 \%+5 \%$

Tablets were withdrawn after a period of $1,2,3$ months and analyzed for physical characterization (appearance, moisture content), study and percentage assay. 
Shraddha Pawan Pareek et al.

\section{Table 7: Formulation of Nifedipine}

\begin{tabular}{llllll}
\hline Ingredients & $\mathbf{N F}_{\mathbf{1}}$ & $\mathbf{N F}_{\mathbf{2}}$ & $\mathbf{N F}_{\mathbf{3}}$ & $\mathbf{N F}_{\mathbf{4}}$ & $\mathbf{N F}_{\mathbf{5}}$ \\
\hline Drug & 20 & 20 & $20 \mathrm{mg}$ & 20 & 20 \\
& $\mathrm{mg}$ & $\mathrm{mg}$ & & $\mathrm{mg}$ & $\mathrm{mg}$ \\
\hline MCCP & 95 & 85 & 78 & 65 & 70 \\
& $\mathrm{mg}$ & $\mathrm{mg}$ & $\mathrm{mg}$ & $\mathrm{mg}$ & $\mathrm{mg}$ \\
\hline Starch & 30 & 34 & 38 & 36 & 40 \\
& $\mathrm{mg}$ & $\mathrm{mg}$ & $\mathrm{mg} \mathrm{m}$ & $\mathrm{mg}$ & $\mathrm{mg}$ \\
\hline P.V.P.K -30 & 10 & 12 & 14 & 15 & $9 \mathrm{mg}$ \\
& $\mathrm{mg}$ & $\mathrm{mg}$ & $\mathrm{mg}$ & $\mathrm{mg}$ & \\
\hline Lactose & 30 & 34 & 36 & 32 & 40 \\
& $\mathrm{mg}$ & $\mathrm{mg}$ & $\mathrm{mg}$ & $\mathrm{mg}$ & $\mathrm{mg}$ \\
\hline Ethyl & 7.5 & 9.5 & 8.4 & 11 & 11.5 \\
cellulose & $\mathrm{mg}$ & $\mathrm{mg}$ & $\mathrm{mg}$ & $\mathrm{mg}$ & $\mathrm{mg}$ \\
\hline Talc & $4 \mathrm{mg}$ & $5 \mathrm{mg}$ & $6 \mathrm{mg}$ & $5 \mathrm{mg}$ & 5.5 \\
& & & & & $\mathrm{mg}$ \\
\hline Aerosil & $1 \mathrm{mg}$ & 1.2 & 1.4 & 1.2 & 1.6 \\
& & $\mathrm{mg}$ & $\mathrm{mg}$ & $\mathrm{mg}$ & $\mathrm{mg}$ \\
\hline Magnesium & 0.3 & 0.5 & 0.6 & 0.5 & 0.6 \\
stearate & $\mathrm{mg}$ & $\mathrm{mg}$ & $\mathrm{mg}$ & $\mathrm{mg}$ & $\mathrm{mg}$ \\
\hline HPMC K-100 & 15 & 21 & 23.2 & 38 & 32 \\
& $\mathrm{mg}$ & $\mathrm{mg}$ & $\mathrm{mg}$ & $\mathrm{mg}$ & $\mathrm{mg} \mathrm{m}$ \\
\hline Ethyl & $9 \mathrm{mg}$ & 9.5 & 8.5 & -- & --- \\
cellulose & & $\mathrm{mg}$ & $\mathrm{mg}$ & & \\
\hline Total weight & 231.9 & 233.7 & 235 & 223.7 & 230.2 \\
& $\mathrm{mg}$ & $\mathrm{mg}$ & $\mathrm{mg}$ & $\mathrm{mg}$ & $\mathrm{mg}$ \\
\hline
\end{tabular}

Journal of Biomedical and Pharmaceutical Research

Table 8: Formulation of Nifedipine Coating Solution

\begin{tabular}{ll}
\hline Ingredients & Quantity \\
\hline HPMC & $6.06 \mathrm{mg}$ \\
\hline Purified talc & $7.580 \mathrm{mg}$ \\
\hline Titanium dioxide & $0.400 \mathrm{mg}$ \\
\hline PEG 6000 & $1.010 \mathrm{mg}$ \\
\hline Col Sunset Yellow & $0.303 \mathrm{mg}$ \\
\hline Isopropyl Alcohol & $60 \mathrm{ml}$ \\
\hline Methylene dichloride & $101 \mathrm{ml}$ \\
\hline
\end{tabular}

\section{RESULT}

Table 9:

\begin{tabular}{lll}
\hline Test & Specification & Observation \\
\hline Color & $\begin{array}{l}\text { Yellow to light } \\
\text { yellow }\end{array}$ & $\begin{array}{l}\text { Yellow to light } \\
\text { yellow }\end{array}$ \\
\hline Odour & Odorless & Odorless \\
\hline Appearance & $\begin{array}{l}\text { Yellow crystalline } \\
\text { powder }\end{array}$ & $\begin{array}{l}\text { Yellow crystalline } \\
\text { powder }\end{array}$ \\
\hline $\begin{array}{l}\text { Loss } \\
\text { drying }\end{array}$ & NMT than $0.5 \%$ & $0.33 \%$ \\
\hline Melting point & $173-175^{\circ} \mathrm{C}$ & $173^{\circ} \mathrm{C}$ \\
\hline $\begin{array}{l}\text { Table } \\
\text { 10: }\end{array}$ & Solubility of & Nifedipine in different \\
\hline Solvents & Solvent & Inference \\
\hline 1 & Water & Insoluble \\
\hline 2 & Chloroform & Freely soluble \\
\hline 3 & Ethanol & Sparingly \\
& soluble \\
\hline 4 & Acetone & Freely soluble \\
\hline
\end{tabular}

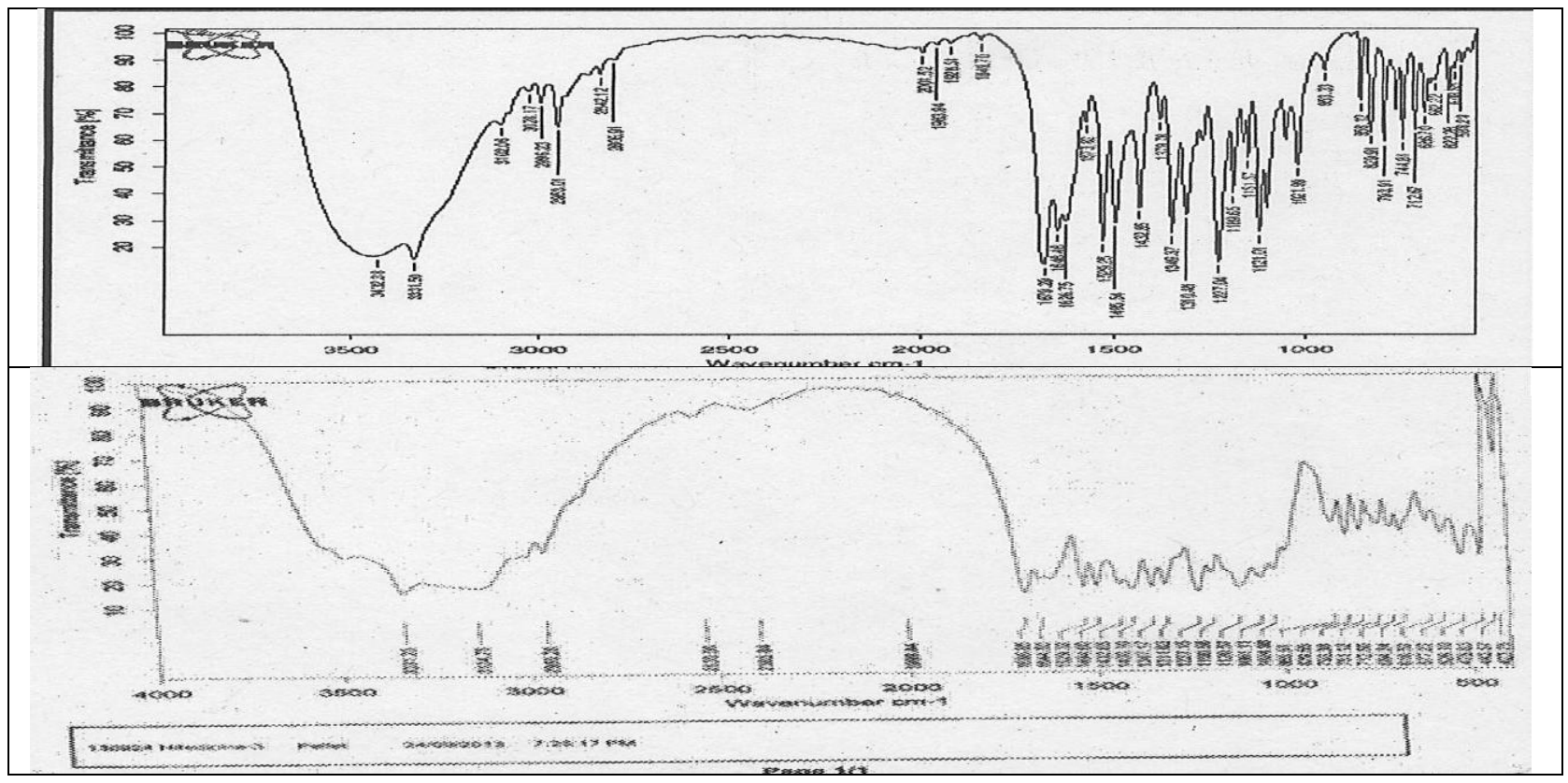

Figure 2: IR Spectra of Pure Nifedipine and Nifedipine with MCC 


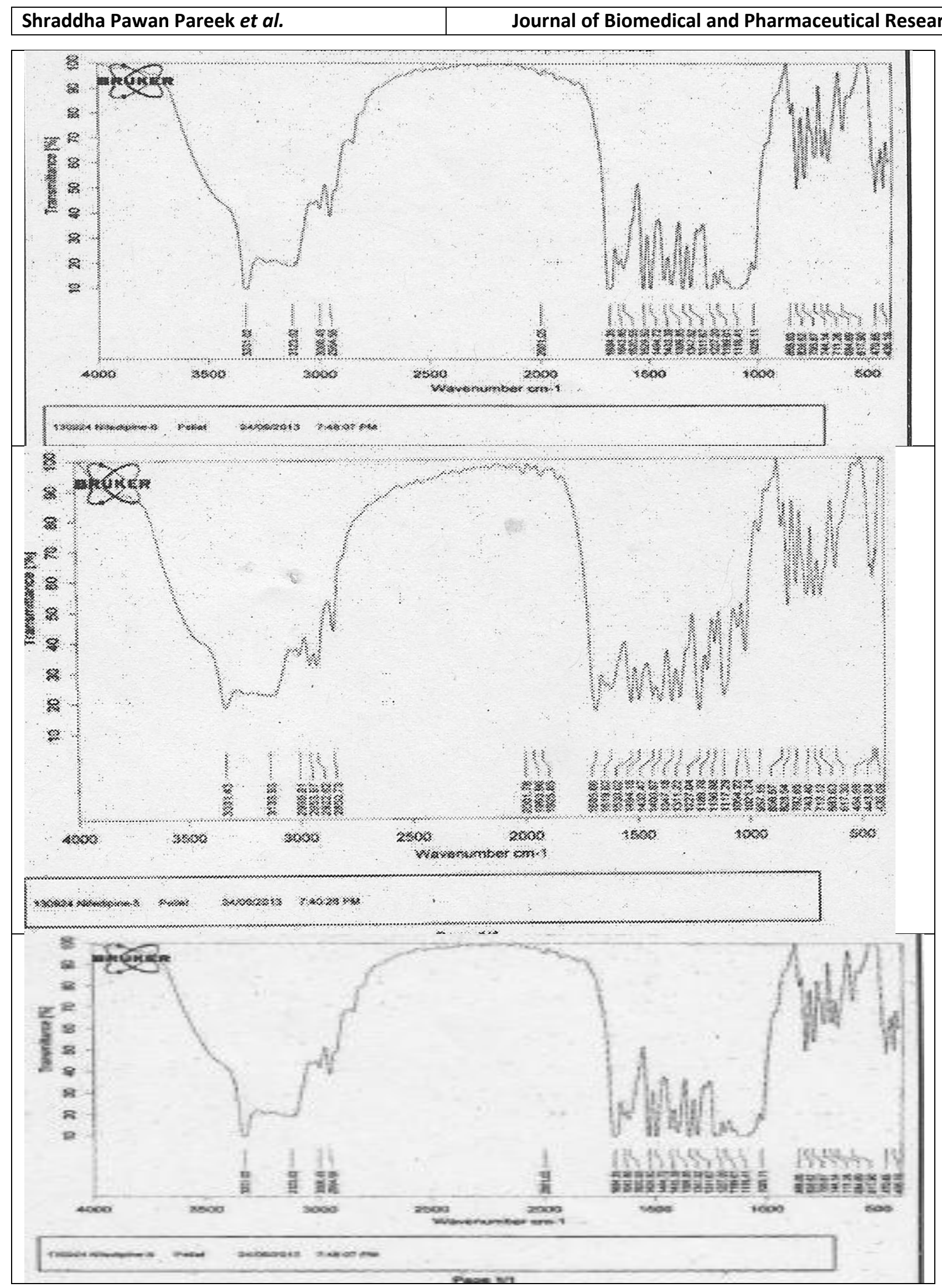

Figure 3: Nifedipine with PVPK-30 and Magnesium Sterate 


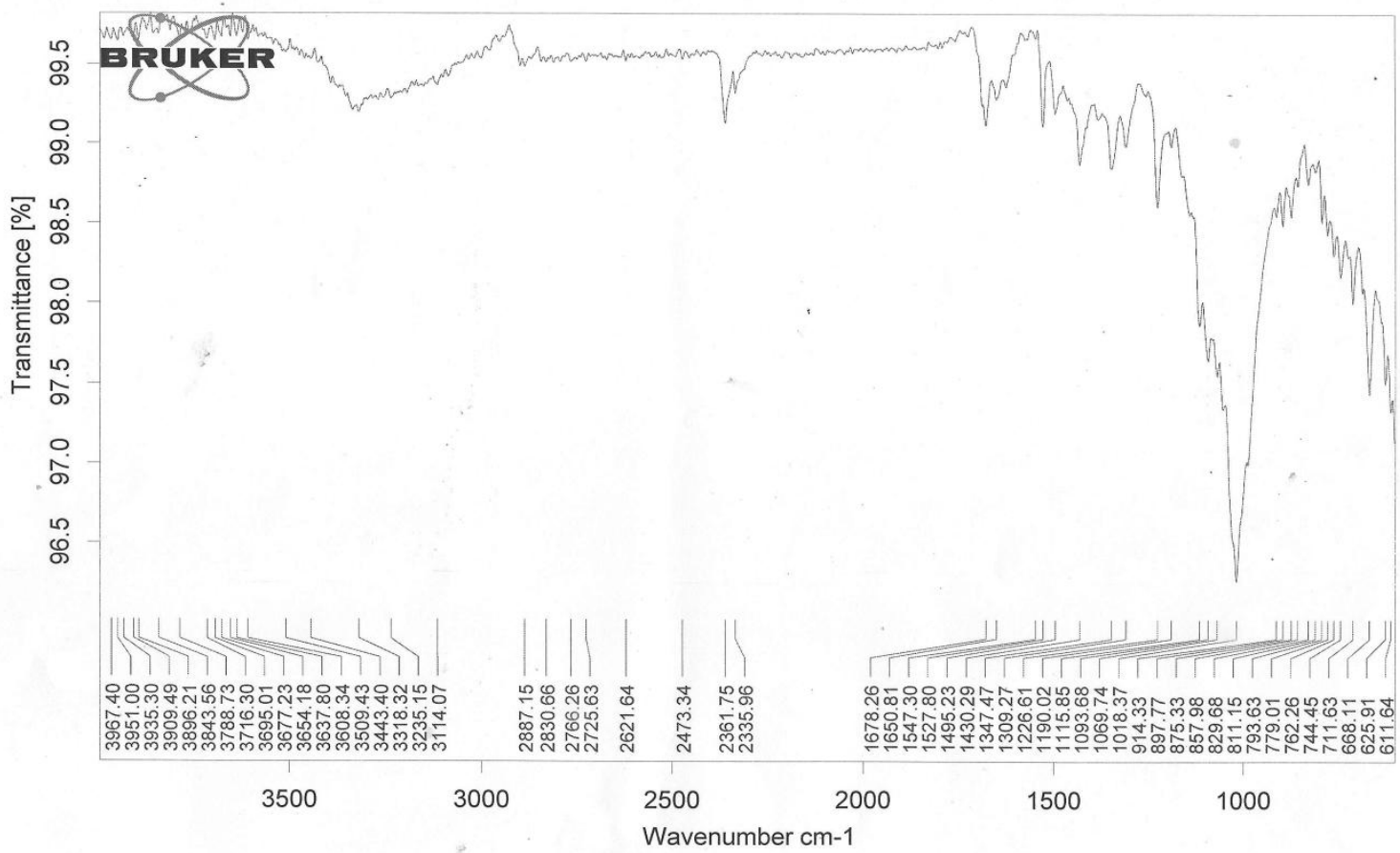

Figure 4: NIFEDIPINE WITH ALL EXCIPIENTS

Table 11: Evaluations of Pre-Compression Parameters

\begin{tabular}{llllll}
\hline Property & NF1 & NF2 & NF3 & NF4 & NF5 \\
\hline Angle of repose $\left(^{\circ}\right)$ & $33^{\circ} 59$ & $33^{\circ} 05$ & $34^{\circ} 02$ & $33^{\circ} 31$ & $33^{\circ} 14$ \\
\hline Bulk density $\left(\mathrm{gm} / \mathrm{cm}^{3}\right.$ & 0.488 & 0.455 & 0.476 & 0.466 & 0.488 \\
\hline Tapped destiny $\left(\mathrm{gm} / \mathrm{cm}^{3)}\right.$ & 0.572 & 0.556 & 0.556 & 0.541 & 0.550 \\
\hline Carr's ratio & 16.6 & 15.5 & 13.9 & 16.20 & 16.6 \\
\hline Hausners ratio & 1.20 & 1.22 & 1.13 & 1.13 & 1.19 \\
\hline Flow property & Good & Good & Good & Good & Good \\
\hline
\end{tabular}

Table 11: POST-COMPRESSION EVALUATION PARAMETERS

\begin{tabular}{llllll}
\hline Formulation & $\begin{array}{l}\text { Weight } \\
\text { variation } \\
\text { Mean }\end{array}$ & $\begin{array}{l}\text { Hardness } \\
(\mathbf{k g} / \mathbf{c m} 2)\end{array}$ & $\begin{array}{l}\text { Friability } \\
(\%) \text { Mean }\end{array}$ & $\begin{array}{l}\text { Thickness } \\
\text { Mean }\end{array}$ & $\begin{array}{l}\text { In vitro disintegration } \\
\text { time }(\mathbf{s e c}) \text { Mean }\end{array}$ \\
\hline NF1 & 2.29 & 2.5 & 0.88 & 2.80 & 17 Mins \\
\hline NF2 & 2.29 & 2.5 & 0.65 & 2.80 & 15 min \&14 sec \\
\hline NF3 & 2.30 & 3.5 & 0.52 & 2.80 & 10 min \& 22 secs \\
\hline NF4 & 2.23 & 2.5 & 1.2 & 2.40 & 8 min 5 Sec \\
\hline NF5 & 2.29 & 3 & 0.7 & 2.80 & 4 mins \\
\hline
\end{tabular}




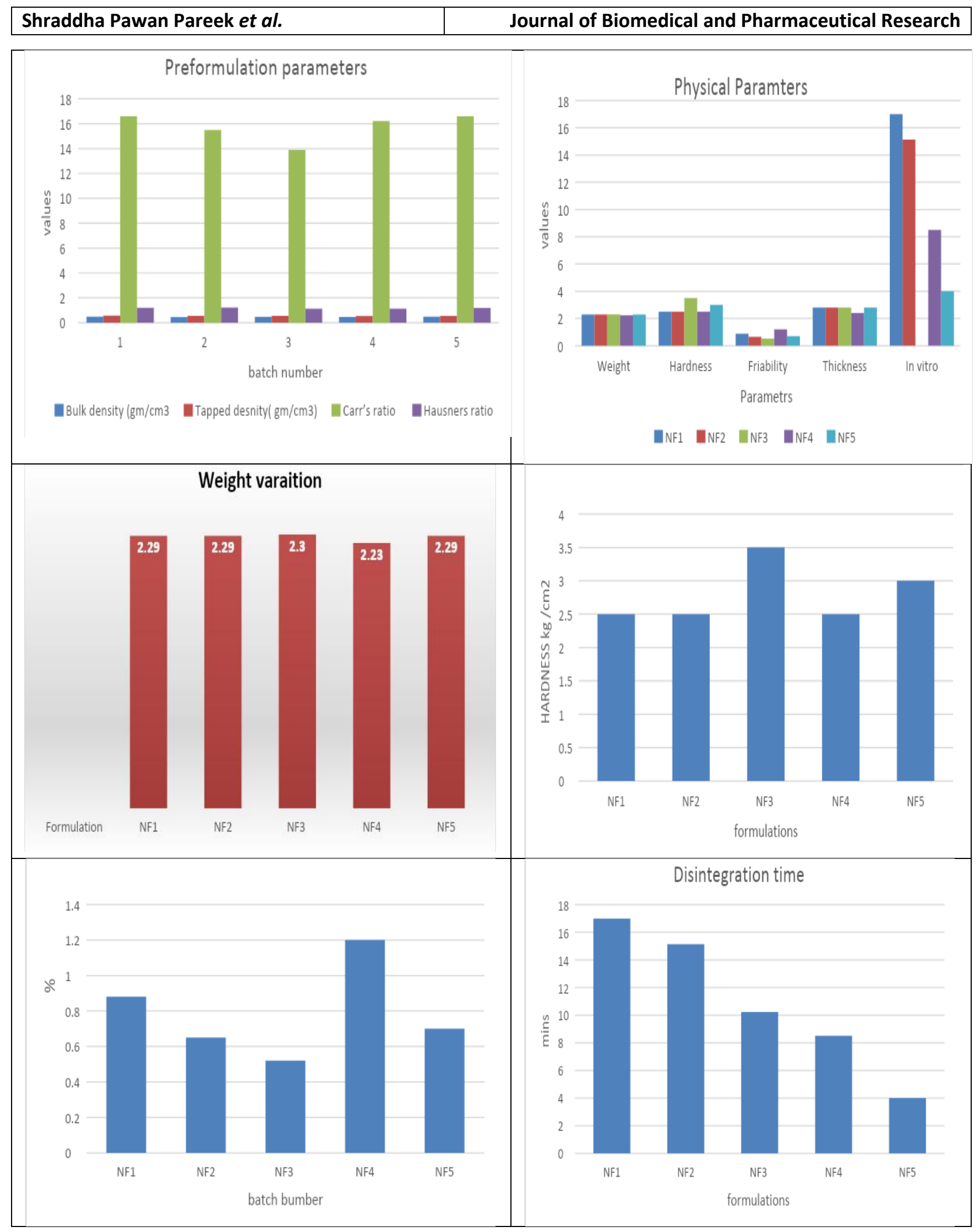

Graph 1: Preformulation Parameter, Weight variation, hardness, disintegration time 
Table 12: Absorbance of Nifedipine

\begin{tabular}{lll}
\hline Sr $\mathbf{n o}$ & Concentration $(\mathbf{m c g} / \mathbf{m l})$ & Absorbance $\mathbf{2 3 7} \mathbf{n m}$ \\
\hline 1 & 0 & 0 \\
\hline 2 & 5 & 0.211 \\
\hline 3 & 6 & 0.252 \\
\hline 4 & 7 & 0.301 \\
\hline 5 & 8 & 0.346 \\
\hline 6 & 9 & 0.390 \\
\hline 7 & 10 & 0.432 \\
\hline
\end{tabular}

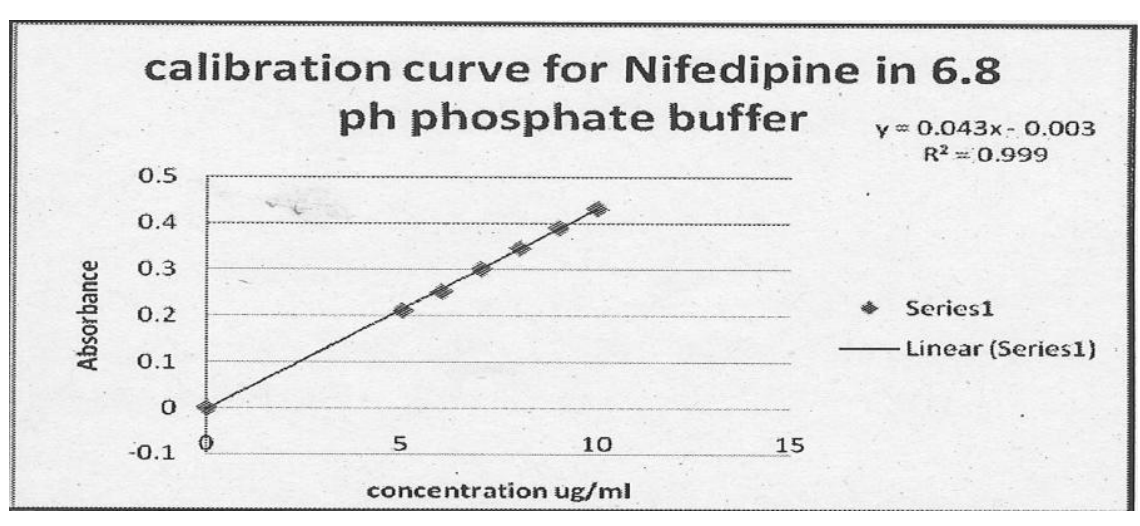

Graph 2: Calibration curve for Nifedipine in $6.8 \mathrm{pH}$ in phosphate buffer

Table 13: In-vitro dissolution study

\begin{tabular}{ccccccc}
\hline Drug release test at hrs & Specification & Batch I & Batch II & Batch III & Batch IV & Batch V \\
& & NF1 & NF2 & NF3 & NF4 & NF5 \\
\hline At 0 hrs & Between 00\% and 00\% & 00 & 00 & 00 & 00 & 00 \\
\hline At 3 hrs & Between 10\% and 30\% & 15.16 & 17.22 & 17.19 & 53 & 41 \\
\hline At 6 hrs & Between 40\% and 65\% & 38.23 & 40.19 & 40.24 & 82 & 76 \\
\hline At 12 hrs & Not less than 80\% & 91.10 & 91.08 & 91.12 & 00 & 00 \\
\hline
\end{tabular}

In-vitro Release Profile of Nifedifine

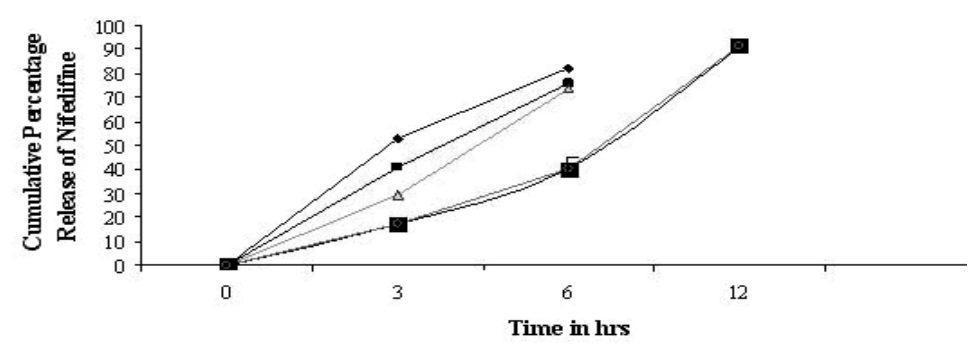

Graph 3: Release profile

Table 14: In-vitro Release of drug of NF3

\begin{tabular}{llllllll}
\hline Time (h) & $\mathrm{Vt}$ & Log $\mathrm{t}$ & $\begin{array}{l}\text { Amount } \\
\text { released } \\
(\mathrm{mg})\end{array}$ & $\begin{array}{l}\text { \% drug } \\
\text { released }\end{array}$ & $\begin{array}{l}\text { \% drug to be } \\
\text { released }\end{array}$ & $\begin{array}{l}\text { Log \% drug } \\
\text { released }\end{array}$ & $\begin{array}{l}\text { Log \% drug to be } \\
\text { released }\end{array}$ \\
\hline 3 & 1.732 & 0.4471 & 3.12 & 17.19 & 82.81 & 1.23527 & 1.91808 \\
\hline 6 & 2.449 & 0.7781 & 8.05 & 40.24 & 59.76 & 1.60465 & 1.77641 \\
\hline 12 & 3.464 & 1.0791 & 18.32 & 91.12 & 8.8 & 1.95961 & 0.94841 \\
\hline
\end{tabular}




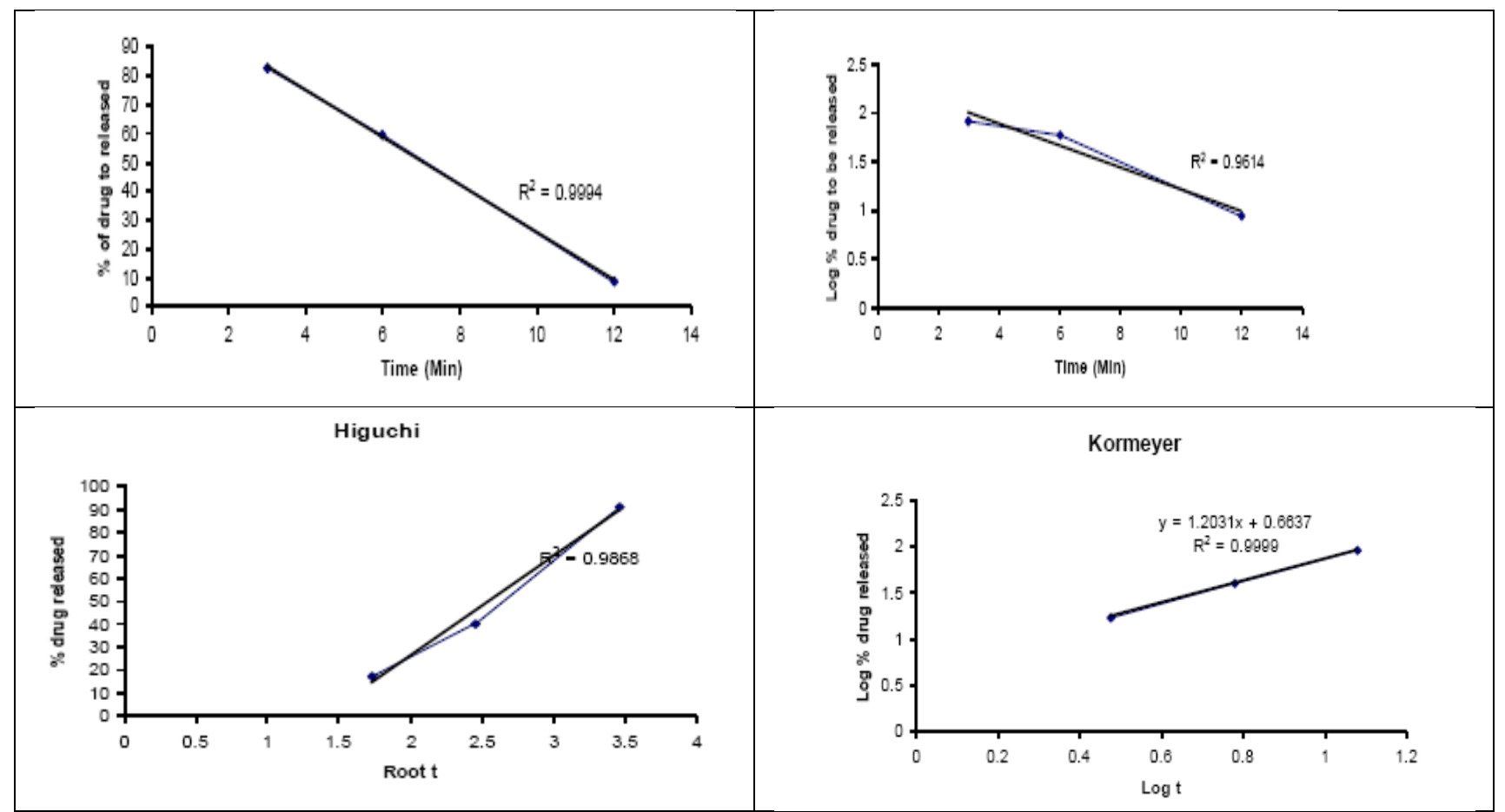

Graph 4: Kinetic release of Nifedipine of Zero Order Reaction, Nifedipine of First Order Reaction, Kinetic release of Nifedipine Higuchi Kinetic release of Nifedipine Kormeyer

\section{STABILTY DATA}

\section{Table 15: REAL TIME STABILITY REPORT}

Product: Nifedipine Sustained Release Tablets $20 \mathrm{mg}$

Storage Conditions: Temperature $30^{\circ} \mathrm{C}+2^{\circ} \mathrm{C}$ and $\mathrm{RH} 65 \%+5 \%$.

\begin{tabular}{|c|c|c|c|c|c|}
\hline \multirow{2}{*}{$\begin{array}{l}\text { Sr. } \\
\text { No }\end{array}$} & \multirow[t]{2}{*}{ Tests } & \multicolumn{4}{|c|}{ FREQUENCY OF TESTING } \\
\hline & & Initial & $\begin{array}{l}1 \\
\text { months }\end{array}$ & $\begin{array}{l}2 \\
\text { months }\end{array}$ & $\begin{array}{l}3 \\
\text { months }\end{array}$ \\
\hline 1 & $\begin{array}{l}\text { Description: Light orange Coloured, circular, } \\
\text { biconvex, sustained released film coated tablet. }\end{array}$ & Complies & Complies & Complies & Complies \\
\hline 2 & Identification: Must comply as per standard & Complies & Complies & Complies & Complies \\
\hline 3 & Weight of 20 Tablets: $4.6000 \mathrm{gm}$ & $4.6082 \mathrm{gm}$ & $4.5996 \mathrm{gm}$ & $4.5877 \mathrm{gm}$ & $4.5739 \mathrm{gm}$ \\
\hline 4 & Average Weight of a Tablet: $0.2300 \mathrm{gm}$ & $0.2304 \mathrm{gm}$ & $0.2298 \mathrm{gm}$ & $0.2294 \mathrm{gm}$ & $0.2287 \mathrm{gm}$ \\
\hline 5 & $\begin{array}{l}\text { Uniformity of Weight: } \\
\pm 7.5 \% \text { Avg. Weight }\end{array}$ & Complies & Complies & Complies & Complies \\
\hline 6 & $\begin{array}{l}\text { Disintegration Time: } \\
\text { NMT } 30 \text { minutes }\end{array}$ & $\begin{array}{l}10 \min . \& 22 \\
\text { sec. }\end{array}$ & $\begin{array}{l}11 \text { min. \& } 00 \\
\text { sec. }\end{array}$ & $\begin{array}{l}11 \text { min. \& } 13 \\
\text { sec. }\end{array}$ & $\begin{array}{l}11 \text { min. \& } 37 \\
\text { sec. }\end{array}$ \\
\hline \multirow[t]{3}{*}{7} & Dissolution Test: & & & & \\
\hline & A) NLT $25.0 \% \& N M T 45.0 \%$ & $33.00 \%$ & $32.27 \%$ & $31.41 \%$ & $30.58 \%$ \\
\hline & B) NLT $60.0 \%$ & $84.00 \%$ & $83.86 \%$ & $88.25 \%$ & $87.58 \%$ \\
\hline \multirow[t]{3}{*}{8} & Assay: Limit: $90.0 \%$ to $110.0 \%$ & & & & \\
\hline & Each sustained release film coated tablet contains: & & & & \\
\hline & Nifedipine & $101.60 \%$ & $101.12 \%$ & $100.64 \%$ & $99.91 \%$ \\
\hline
\end{tabular}


Table 16: ACCELERATED TIME STABILITY REPORT

Product: Nifedipine Sustained Release Tablets $20 \mathrm{mg}$

Storage Conditions: Temperature $40^{\circ} \mathrm{C}+2^{\circ} \mathrm{C}$ and $\mathrm{RH} 75 \%+5 \%$.

\begin{tabular}{|c|c|c|c|c|c|}
\hline \multirow{2}{*}{$\begin{array}{l}\text { Sr. } \\
\text { No }\end{array}$} & \multirow[t]{2}{*}{ Tests } & \multicolumn{4}{|c|}{ FREQUENCY OF TESTING } \\
\hline & & Initial & $\begin{array}{l}1 \\
\text { months }\end{array}$ & $\begin{array}{l}2 \\
\text { Months }\end{array}$ & $\begin{array}{l}3 \\
\text { months }\end{array}$ \\
\hline 1 & $\begin{array}{l}\text { Description: Light orange coloured, circular, } \\
\text { biconvex, sustained released film coated tablet. }\end{array}$ & Complies & Complies & Complies & Complies \\
\hline 2 & Identification: Must comply as per IP & Complies & Complies & Complies & Complies \\
\hline 3 & Weight of 20 Tablets: $4.6000 \mathrm{gm}$ & $4.6082 \mathrm{gm}$ & $4.5961 \mathrm{gm}$ & $4.5877 \mathrm{gm}$ & $4.5739 \mathrm{gm}$ \\
\hline 4 & Average Weight of a Tablet: $0.2300 \mathrm{gm}$ & $0.2304 \mathrm{gm}$ & $0.2298 \mathrm{gm}$ & $0.2294 \mathrm{gm}$ & $0.2287 \mathrm{gm}$ \\
\hline 5 & $\begin{array}{l}\text { Uniformity of Weight: } \\
\pm 7.5 \% \text { Avg. Weight }\end{array}$ & Complies & Complies & Complies & Complies \\
\hline 6 & $\begin{array}{l}\text { Disintegration Time: } \\
\text { NMT } 30 \text { minutes }\end{array}$ & $\begin{array}{l}10 \text { min. \& } 22 \\
\text { sec. }\end{array}$ & $\begin{array}{l}11 \text { min. \& } 00 \\
\text { sec. }\end{array}$ & $\begin{array}{l}11 \text { min. \& } 13 \\
\text { sec. }\end{array}$ & $\begin{array}{l}11 \text { min. \& } 37 \\
\text { sec. }\end{array}$ \\
\hline \multirow[t]{3}{*}{7} & Dissolution Test: & & & & \\
\hline & A)NLT $25.0 \% \& N M T 45.0 \%$ & $33.00 \%$ & $32.27 \%$ & $31.41 \%$ & $30.58 \%$ \\
\hline & B) NLT $60.0 \%$ & $84.00 \%$ & $83.86 \%$ & $88.25 \%$ & $87.58 \%$ \\
\hline \multirow[t]{3}{*}{8} & Assay: Limit: $90.0 \%$ to $110.0 \%$ & & & & \\
\hline & Each sustained release film coated tablet contains: & & & & \\
\hline & Nifedipine & $101.60 \%$ & $101.12 \%$ & $100.64 \%$ & $99.91 \%$ \\
\hline
\end{tabular}

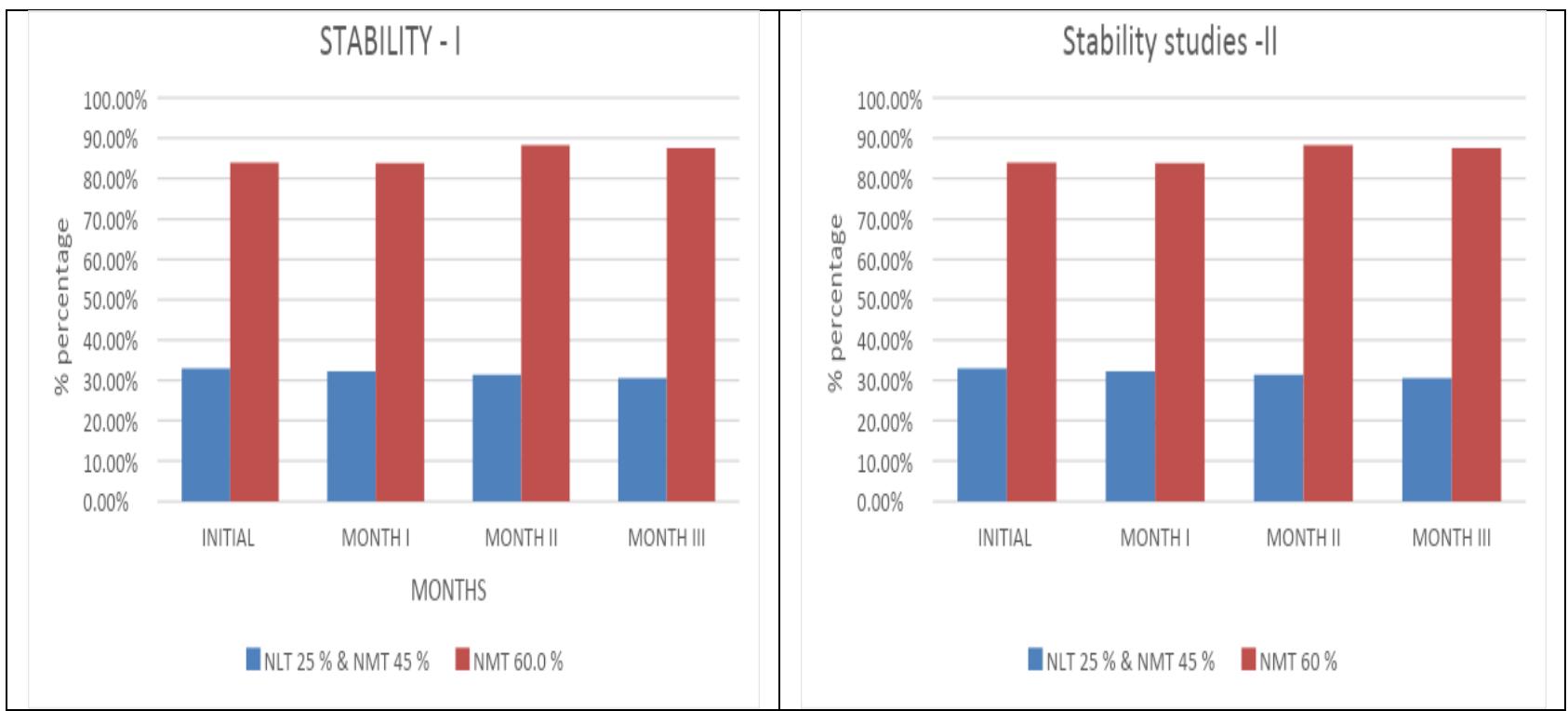

Graph 5: stability Graph

\section{DISCUSSION}

The Drug selected for Research Work is Nifdipine Anti-Angina \& Antihypertensive drug the Drug Sample was firstly identified for various Pharmacopoeial test as well as analyzed by spectrometrically and By FTIR and the results showed Authencity and purity of drug sampl. The melting Point of the drug with Appearance
Solubility, Odour and loss on drying were determined which is matched the standard. The Melting Point was Found $173-175^{\circ} \mathrm{C}$ which matched the standard. Solubility of drug was freely soluble I chloroform and acetone and completely insoluble in water. LOD was found to be $0.33 \%$ which was in the standard limit.Standard curve of Nifedipine was prepared by Shimadzu UV 
Spectrophotometer . at $237 \mathrm{~nm}$.The results showed that it follows the concentration range and follows Beer Lambert law. Drug Excipients interaction was determined by infrared Spectroscopy. The IR Mixture of the drug sample and excipients was found to be within the specified range. Hence there is no interaction between sample and excipients and excipients likely to be used in the formulation $\mathrm{n}$ hence can be used in the formulations. The flow properties of the samples were found optimum and in standard Limit, The Sample NF3 was found optimal in the Parameters and was subjected to further studies in Assay and Stability Studies. The Dissolution Profile also concluded that NF3 release the drug as per the specifiecations. Dissolution of NF1 \& NF2 were also in the standard range As comapared to that Of NF4 \& NF5 Release of NF3 was better after 3, 6\& $12 \mathrm{hrs}$ . The drug release after $12 \mathrm{hrs}$ was $91.12 \%$. From these graphs the kinetic values were calculated by linear regression $(r 2)$ analysis and least square techniques. The data was plotted as \% drug released (Vs) time has indicated that the release rate is almost linear. The linear regression value was found to be 0.9994 , which indicates that the release rate is satisfying the zero order kinetics. The graph is shown in above figure The data was also drawn according to first order rate kinetics and the plot is shown in above figure The linear regression value was found to be 0.9614 . The data has satisfied zero order release of the drug than first order rate of release. Higuchi's square root dependent diffusion equation in which the \% drug release was plotted against time and plot is shown in figure 21 . The plot is linear. This indicates that the diffusion mechanism is operative. The linear regression value 0.9868 . So the drug release obeys diffusion mechanism, with zero order rates. Peppas exponential equation in which the log \% drugs release was plotted against log time. The plot was found to be the linear regression value was 0.999. This indicates that there is significant swelling in the matrix during dissolution time and the mechanism of drug release is anomalous diffusion. The stability Studies of NF3 also found satisfied. Which indicated that drug was stable for 3 months . Which was done as Per the $\mathrm{ICH}$ guidelines on real time and accelerated. Accelerated Temperature $40^{\circ} \mathrm{C}+2^{\circ} \mathrm{C}$ and $\mathrm{RH} 75 \%+$ $5 \%$, real time Temperature $30^{\circ} \mathrm{C}+2^{\circ} \mathrm{C}$ and $\mathrm{RH} 65 \%$
+ $5 \%$. The sample complies with all the parameters included.

\section{CONCLUSION}

Nlifedipine is very efficient for anti-anginal and hypertension. In present Study sustained Release nifedipine tablets were prepared and evaluated .work has shown that Sustained Release may be an interesting choice for hypertension. It Provide a sustained release over the period of $12 \mathrm{hrs}$. Nifedipine was prepared with HPMC \& ethyl cellulose and were sustained Release, efficiency, Drug release, Stability and assay with all physical parameter.

- Preformulation studies were carried on various Parameter were Performed Like Physiochemical Properties, Solubility ,pH and Identification of drug .

- Suitable method based on UV Visible Spectrophotometer was developed at $237 \mathrm{~nm}$ and interference was verified and found that Nifedipine did not interfere with the polymer and excipients used.

- Matrix formation was used to prepare the tablets.

- Evaluation Was within Permissible limit of formulation.

- In-vitro drug Release Study of all the formulation was carried out and based on the result NF3 batch of sustained Release tablet was identified as the best Formulation among all the formulations

\section{Acknowledgement}

The authors thank the management and principal of Goenka College of Pharmacy, Lacchmangarh, Sikar, Rajasthan (India) for providing various facilities to complete the work.

\section{Reference}

1. US Pharmacopeia XXVII. Rockville, US Pharmacopoeial convention; 2004: 2303-2307, 2514- 2515.

2. Lee VHL and Robinson JR. In: Robinson, JR. Sustained and Controlled Release Drug Delivery Systems. 1978:6.

3. Lee $P$ and Good W. Overview of Controlled Release Drug Delivery. In Controlled Release 
Technology: Pharmaceutical Applications. ACS Symposium Series 348, American Chemical Society, Washington D.C. 1987:1-13.

4. Chien YW. Novel drug delivery system., 2nd edition, Marcel Dekker, INC., 1992:1-43, 44-139, 140-197

5. Banker GS and Rhodes CT. Modern Pharmaceutics. 2nd edition, Marcel Dekker, INC., 1996:635- 671.

6. Chang RK and Robinson JR. Tablets. In: Lieberman HA, Lachman L. Pharmaceutical Dosage Forms.New York, Vol.3, Marcel Dekker, 1990:206.

7. Chien YW, Lin S, Swarbrick J and Boylan J. Drug Delivery- Controlled Release In "Encyclopedia of Pharmaceutical technology"; New York, second edition; vol-I; Ed. Marcel Dekker; 2002:811.

8. Chang RK and Robinson JR. Tablets. In: Lieberman, HA, Lachman L. Pharmaceutical Dosage Forms. New York, Vol.3, Marcel Dekker; 1990:200.

9. Tabandeh $\mathrm{H}$, Mortazavi SA and Guilani TB. Preparation of sustained release matrix tablets of aspirin withethyl cellulose, Eudragit RS 100 and Eudragit S 100 and studying the release profile and their sensitivity to tablet hardness. Iranian J Pharm Res. 2003:201 - 206.

10. Shargel L, Andrew BC and Yu In. Applied Biopharmaceutics and Pharmacokinetics. New York $4^{\text {th }}$ Ed.Prentice-Hall International. 1999:139.

11. Jerome PS and William HR. In: Robinson JR, Lee VHL. Controlled Drug Delivery: Fundamentals and Applications. New York 2nd Ed. Marcel Dekker; 1987:295.

12. Costa $P$ and Sousa JM. Modeling and comparison of dissolution profiles. Eur J Pharm Biopharm. 2001;13:123 - 133 .

13. Dredan J, Antal I and Racz I. Evaluation of mathematical models describing drug release from lipophilic matrices. Int J Pharm. 1996;145:61 -64.

14. Reza MS, Quadir MA and Haider SS. Comparative evaluation of plastic, hydrophobic and hydrophilic polymers as matrices for controlled - release drug delivery. J Pharm Pharmac Sci. 2003;6(2):282 291.

15. Katikaneni $R$, Upadrashta $M$ and Mitra $K$. Ethylcellulose matrix controlled release tablets of a water soluble drug. Int J Pharm. 1995;123:119-125.

16. Augsburger L, Rekhi GS andNellore VR. Identification of critical formulation and processing variables for metoprolol tartarate extended release (ER) matrix tablets. J Control Rel. 1999;59:327-342.

17. Sako $\mathrm{K}$ and Nakashima $\mathrm{H}$. Influence of water soluble fillers in hydroxypropylmethyl cellulose matrices on invitro and invivo drug release. J Control Rel. 2002;81:165-172.

18. Peppas A, Baumgartner S and Kristl J. Network structure of cellulose ethers used in pharmaceutical application during swelling and at equilibrium. Pharm Res. 2002;19(8):1084-1090.

19. Makhija SN and Vavia PR. Once daily release tablets of Nifedipine, a novel antidepressant. Eur J Pharm Biopharm. 2002;54:9 - 15.

20. Tiwary $A K$, Kuksal $A$, Jain $\mathrm{N}$ and Jain $\mathrm{S}$. Formulation and invitro, Invivo evaluation of zidovudine: influence of combination of hydrophilic and hydrophobic matrix formers. AAPS PharmsciTech. 2006;7(1):1-9.

21. Birudaraj R, Berner B, Shen S. Buccal permeation of buspirone: Mechanistic studies on transport pathways. J Pharm Sci 2005; 94: 70-78.

22. Ishikawa T, Koizumi N, Mukai B, Utoguchi N, Fujii $M$, Matsumoto $M$ et al., Pharmacokinetics of acetaminophen from rapidly disintegrating compressed tablet prepared using microcrystalline cellulose (PH-M-06) and spherical sugar granules. Chem Pharm Bull (Tokyo) 2001; 49: 230-232.

23. Price $T M$, Blauer KL, Hansen $M$, Stanczyk F, Lobo R, Bates GW. Single-dose pharmacokinetics of sublingual versus oral administration of micronized 17 beta-estradiol. Obstet Gynecol. 1997; 89: 340345.

24. Croom, Katherine F, Wellington, Keri. Modifiedrelease nifedipine: A review of the use of modified release formation in the treatment of hypertension and Angina pectoris. Drugs; 2006; 66 Suppl 4: 497528.

25. Richard D Howland, Mary J Mycek Lippincott's Reviews pharmacology, $3^{\text {rd }}$ ed. Philadelphia: Lippincott Williams and Wilkins; 1997. p. 211.

26. Anthony J Trevor, Bertram G Katzung, Usan B Masters Katzung and Trevor's Pharmacology, $7^{\text {th }}$ ed. Singapore: McGraw Hill medical publishing; 2005. p.110.

27. Sean C Sweetman Martindale, The complete drug reference, Vol 34, USA: Pharmaceutical press; 2005. p.967. 